\title{
Quality of life in simultaneous pancreas-kidney transplant recipients
}

\author{
Pilar Isla Pera ${ }^{\mathrm{a}}$, Joaquin Moncho Vasallo ${ }^{\mathrm{b}}$, Alberto Torras Rabasa ${ }^{\mathrm{c}, \mathrm{d}}$, Federico \\ Oppenheimer Salinas ${ }^{c}$, Laureano Fernández Cruz Pérez ${ }^{\text {d,e }}$, María José Ricart Brulles ${ }^{c}$ \\ ${ }^{a}$ Public Health Department. Nursing School. Universitat de Barcelona, Spain; ${ }^{b}$ Public

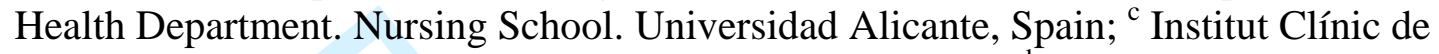 \\ Nefrología i Urología. Hosp. Clínic de Barcelona, Spain; ${ }^{\mathrm{d}}$ Facultat de Medicina. \\ Universitat de Barcelona, Spain; ${ }^{\mathrm{e}}$ Institut Clínic de Malalties Digestives. Hosp. Clínic de \\ Barcelona, Spain. \\ Corresponding author::Pilar Isla Pera. Sant Gervasi de Cassoles, 80, Esc. A, $2^{\circ} 1^{\mathrm{a}} .08022$ \\ Barcelona \\ Telephone: Work: 934024241; home: 932116467 Fax: 934024297 \\ e-mail: pisla@ub.edu
}

(This study was supported by the Fondo de Investigaciones Sanitarias (2004-06) Ministry of Health and Consumption, Spain (grant number P1041210) 


\section{Introduction}

Currently, simultaneous pancreas-kidney transplantation (SPK Tx) is the treatment of choice in selected patients with type 1 diabetes mellitus (DM1) and terminal kidney failure (TRF). A functioning SPK transplant allows dialysis and insulin therapy to be discontinued and stabilizes or improves the complications of DM1. Nevertheless, to a greater or lesser degree, these complications (physical and psychological alterations, secondary effects of immunosuppressive therapy and the need for lifelong medication and medical follow-up) can persist after SPK Tx. Health professionals have mainly investigated the clinical features of transplant recipients. However, in the last few years, interest in analyzing perceived health and health-related quality of life (QoL) has increased. This latter concept includes the features of QoL most closely associated with a particular disease, its treatment and follow-up and therefore those elements most susceptible to modification by the health system.

The general aim of this study was to measure health-related QoL in our population with SPK Tx and to determine whether there are significant differences between these patients and those with DM1 and TRF who continue to receive renal replacement therapy (RRT) and insulin therapy. More specific aims were to evaluate whether there are significant differences between the study groups and the means of the Spanish reference population in the distinct dimensions of a QoL questionnaire and whether other variables such as age, sex, years’ duration of DM1, length of dialysis, and time since SPK Tx significantly affect health-related QoL. 


\section{Patients and methods}

From 2004-2005, we performed a cross-sectional study of health-related QoL in 69 patients who underwent SPK Tx in Hospital Clínico de Barcelona from 1998-2002 and in 34 patients with DM1 and TRF undergoing RRT in hospitals or health centers in Catalonia (Spain) and included on the waiting list for an SPK or kidney transplant alone. Inclusion criteria were maintained function in both grafts in SPK transplant recipients, and DM1 and TRF, age equal to or less than 55 years, and length of RRT longer than 1 year in patients under RRT. Before patients receiving RRT were included in the study, the consultant in charge of each patient confirmed that the patient had no severe vascular or neuropathic complications (potentially treatable severe peripheral vascular disease or coronary heart disease, or disabling motor or autonomic neuropathy).

To evaluate QoL, the Spanish version of the Medical Outcomes Study 36-Item Short Form Health Survey (SF-36) was selected as it is one of the most widely used instruments, all articles published on its metric properties support is reliability, validity and sensitivity, and no differences have been found in its internal consistency between self-administered questionnaires and those administered through interview (1). The SF36, developed by Ware $(2,3)$ and adapted and validated by Alonso et al. (4), is a generic QoL questionnaire containing 36 items grouped in the following eight scales: physical functioning, role limitations-physical, bodily pain, general health, vitality, social functioning, role limitations-emotional, and mental health. There is also an item that assesses perception of changes in health status compared with health 1 year previously. 
In addition to the SF-36, the following variables were recorded: type of treatment (SPK Tx or RRT), type of RRT (haemodialysis or peritoneal dialysis), sex, age, DM1 duration, and length of RRT. All the questionnaires were self-administered except in four patients in whom telephone interviews were carried out.

For the data analysis, the instructions for the standardization of content and scoring of the Spanish version of the SF-36 were followed (5). To calculate the scores, the following steps were performed: scoring was reversed in 10 items requiring this step so that high scores always indicated better health; secondly, the sum of all the items composing each scale was calculated; and thirdly, linear transformation of crude scores was carried out to obtain scores on a scale of $0-100$. Thus, for each dimension, the items were codified, summed, and transformed on a scale ranging from 0 (worst health status on this dimension) to 100 (best health status).

\section{Statistical analysis}

Descriptive analysis of the variables was performed by calculating frequencies for qualitative variables and means, standard deviation, median and range for quantitative variables, as well as 95\% confidence intervals for means. To analyze the association between the scores obtained on the SF-36 and clinical and sociodemographic variables, the chi-squared test or Fisher's exact test were used. To compare means, Student's t-test or the Mann-Whitney U-test were used, depending on the sample size of each group and the number of different values observed in each of the variables. 
Subsequently, to determine whether there were statistically significant differences in QoL dimensions between SPK transplant recipients and patients under RRT, adjusted by other variables that could influence these dimensions, a multiple linear regression model and/or two-way ANOVA with covariables and interaction effects were constructed. Independent variables were sex, age, duration of DM1, study group, and length of dialysis. In variables significantly departing from normal distribution, transformation of the dependent variable was performed. In all the models constructed, possible multicolinearity and the potential effects of interaction were studied. Nonsignificant variables and interaction effects were removed from the model. In dimensions showing few values in their distribution, an ordinal regression (PLUM) model was constructed. The binomial test was used to compare the scores obtained on the QoL dimensions with the means of the Spanish reference population according to sex and age and according to the year in which SPK Tx was performed.

\section{Results}

Sixty-nine SPK transplant recipients and 34 patients receiving RRT met the inclusion criteria. All patients completed the questionnaire (self-administered in 99 and performed through telephone interview in four). No significant differences were found between the two groups in age and sex. In contrast, significant differences were found in DM1 duration and length of RRT (Table 1).

Perception of current health status compared with health 1 year previously was better in SPK transplant recipients than in patients under RRT (Table 2). QoL was higher in SPK transplant recipients than in patients receiving RRT, with significant differences 
in all dimensions (Table 3). In both groups, QoL was lower in women than in men (Tables 4 and 5).

Multivariate analysis revealed that SPK Tx was significantly associated with improved QoL in all dimensions of the SF-36. In both groups, sex, age and DM1 duration were significantly related to QoL. Female sex was negatively associated with the dimensions of mental health, bodily pain, vitality, role limitation-emotional, and physical functioning. Age was positively associated with mental health and a no significant negative association was found with general health $(\mathrm{p}=0.053)$. Duration of DM1 was negatively associated with the dimensions of mental health and bodily pain (Table 6). Significant differences were observed according to the year in which SPK Tx was performed. In almost all domains of the SF-36, the highest scores corresponded to the most recently transplanted patients (Table 7).

Comparison of the results with the means of the reference population showed significant differences according to study group and sex. In SPK transplant recipients, men scored significantly lower than the reference population in the dimensions of general health, role limitations-physical and role limitations-emotional but scored significantly higher in the dimension of vitality. Women with SPK transplants scored significantly lower than the reference population in the dimension of general health.

In patients undergoing RRT, men scored significantly lower than the reference population in the dimensions of physical functioning, bodily pain, general health, and vitality. Women undergoing RRT scored significantly lower than the reference population in all dimensions of the SF-36 (Table 8). 
Comparison of the means obtained in SPK transplant recipients with those for the reference population according to the year in which transplantation was performed revealed that patients who received a transplant in the last year of the study, i.e., those most recently transplanted, showed higher scores than the reference population on the dimensions of role limitations-physical, vitality, and role limitations-emotional. SPK transplant recipients scored significantly lower than the reference population in the domains of physical functioning in 2000 and 2002, in role limitations-physical in 1999 and in general health in 1999, 2000 and 2001 (Table 9).

\section{Discussion}

In the present study, QoL was higher in SPK transplant recipients than in patients receiving RRT in all dimensions of the SF-36 and this result held constant when adjustment was made for other variables such as type of treatment (SPK Tx or RRT), sex, age, DM1 duration, and length of RRT. These results coincide with those studies that have shown the effectiveness of SPK Tx in improving QoL (6-8) and with other studies that have shown the association between RRT and increased stress, anxiety, impaired self image, and reduced QoL (9-11.

Women expressed a greater degree of physical and emotional limitation and therefore lower QoL than men, independent of treatment. Some studies have found no significant differences according to sex and have even found higher QoL in women, mainly in mental health (12). However in most studies, female sex has been associated with poorer perceived health and QoL, both in healthy individuals and in those with disease $(1,13)$. 
Age has frequently been associated with worse QoL $(1,14,15)$. However, in the present study, greater age was associated with better QoL, possibly because the patients studied were not elderly. The negative effects of age on QoL could be due not only to the effect of disease but also to that of the functional deterioration found in the elderly. In addition, as suggested by other authors (16), the SF-36 may be able to discriminate between the effect of disease and treatment and that of age on QoL.

The association between age and better QoL has been observed in studies of patients under RRT and in kidney transplant recipients $(12,16)$ and is in agreement with other studies demonstrating that having a chronic disease and being young is associated with psychological disorders and impaired QoL (17). These findings could be explained by the difficulty of young people in coping with chronic health problems while attempting to forge a life. Patients receiving prolonged treatment may have difficulties in adapting to the disease, its treatment, lifestyle limitations and associated stigma (18). In the present study, although both groups underwent prolonged treatment, RRT was associated with greater dependency and more evident stigma.

Comparison of the results obtained with the means of the reference population revealed that both SPK transplant recipients and patients under RRT had worse QoL, although male SPK transplant recipients scored better than the reference population on the dimension of vitality. In a recent qualitative study, some SPK transplant recipients reported that after transplantation they had recovered their "health", as well as their enjoyment of life, social relationships and, in some cases, sexual and reproductive function and occupational activity (14). However, the present study would indicate that, despite the perception of “cure” and the improvement achieved, SPK transplant recipients 
show a variety of symptoms and require treatment and medical follow-up, all of which reduces their QoL, mainly the dimension of general health. Other authors have revealed that the improvement in QoL after Tx does not reach QoL levels in the general population (19).

Women with SPK transplants obtained lower scores and therefore showed worse QoL than men with SPK transplants in all dimensions. However fewer significant differences with respect to the reference population were observed in women. This result could be due to the smaller number of women than men in this study, reducing statistical power.

The highest QoL scores were observed in the most recently transplanted patients. These patients had a greater perception of improvement compared with health 1-year previously, showed higher values than the reference population in several dimensions, and showed a negative significant difference only in the dimension of physical functioning. These results coincide with those of other studies that have revealed decreased QoL in transplanted patients over time $(12,20)$. The study period in the present study comprised the beginning of 1998 to the end of 2002, with data collection in 2004. Consequently, SPK transplant recipients had a transplant duration of between 1 and 6 years. Patients who underwent SPK Tx in the final year of the study (2002) had a transplant duration of slightly more than 1 year (those transplanted at the end of 2002 and interviewed at the beginning of 2004) or 3 years (patients transplanted at the beginning of 2002 and interviewed at the end of 2004), demonstrating that the improvement in QoL after SPK Tx is maintained after the first year. 
These results differ from those of other studies. Some studies report that transplanted patients experience a state of euphoria in the first year after transplantation due to improvements in physical, social, occupational and sexual function (21-22) and that the results of QoL evaluation tend to reach a peak (21) before decreasing. Other studies have reported that QoL in transplant recipients undergoes temporal oscillations. A study in kidney transplant recipients observed that QoL improved during the first 6 months and then deteriorated before improving again after the first 3 years (23). Pérez San Gregorio et al. (22) reported that transplant recipients pass through three phases: a first phase in which they require treatment and intense medical follow-up and experience difficulties in social and occupational integration, fear of graft rejection, and possible alterations in family dynamics as a result of transplantation; a second phase of adaptation, and a third phase of mental and physical exhaustion in which psychological disturbances increase. This latter phase begins some time after the first 2 years of transplantation.

The possible limitations of this study are due to the relatively small number of patients studied. However, it is important to note that the sample of SPK transplant recipients studied represents $100 \%$ of those undergoing this surgery in the study period who maintained two functioning grafts, that the number of patients under RRT represents a high percentage, given the strict inclusion criteria applied, and that significant differences were detected. Socioeconomic or cultural variables that could have influenced the results were not taken into account. Although not all studies have found an association with these factors (16), socioeconomic position has been found to be correlated with perceived QoL (41). Finally, the SF-36 does not include some health factors, such as sleep disorders and cognitive, family or sexual functions. 
Despite these limitations, multivariate analysis revealed that SPK Tx is positive predictive factor of QoL. We believe that this type of study is justified by the importance of determining the improvement in QoL after SPK Tx. Several studies have reported clinical improvement in patients after SPK Tx. Sustained normal blood glucose and HbA1 levels seem to stabilize retinopathy (25), improve neuropathy (26), protect the kidney transplant from the risk of recurrence of diabetic nephropathy (27), and decrease cardiovascular risk (28-29). However, changes in patients’ lives cannot be determined by clinical and biological improvements alone.

QoL is a multidimensional concept that includes objective and subjective evaluation of the physical, psychological and social factors that determine well being or its absence. Although controversial, the most important and reliable indicators of QoL are subjective, since they express the degree of well being or limitation perceived by the patient and the effect on QoL. Determining the factors associated with QoL in patients with SPK Tx and in those receiving RRT is essential for the development of strategies able to improve these patients’ perceived well being. Several studies have observed that emotional and psychological factors are the most important predictive factors in perceived QoL after transplantation $(12,30)$ and that these factors can be modified by psychological support (31).

The results of the present study demonstrate that SPK Tx improves QoL and that QoL in SPK transplant recipients continued to be better than that in patients receiving RRT and insulin during the study period, although QoL was lower than that in the reference population. Negative predictive factors of QoL were female sex, RRT and DM1 duration. Positive predictive factors of QoL were SPK Tx and greater age. The highest 
QoL was found in patients most recently undergoing SPK Tx, who also showed higher values in some domains than the reference population. Age is a positive predictive factor of mental health and a negative predictive factor of the dimension of role limitationphysical. Future studies should combine QoL analysis with qualitative methodology, which provides more exhaustive information, serial QoL evaluations to determine temporal variations, and the perspective of gender to elucidate the sex differences observed in QoL. 


\section{References}

1. VILAGUT G, FERRER M, RAJMIL L et al. El cuestionario de salud SF-36 español: una década de experiencia y nuevos desarrollos. Gaceta Sanitaria 2005: 19(2): 135.

2. WARE JE, SHERBOURNE CD. The MOS 36-item short-form health survey (SF-36). I. Conceptual framework and item selection. Med Care 1992: 30: 473. 3. MCHORNEY CA, WARE JE, LU JFR et al. The MOS 36-item short-form health survey (SF-36): III. Tests of data quality. Scaling assumptions, and reliability across diverse patient groups. Med Care 1994: 32: 40..

4. ALONSO J, PRIETO L, ANTÓ JM. La versión española del SF-36 health survey (cuestionario de salud SF-36): un instrumento para la medida de los resultados clínicos. Med Clin (Barc) 1995: 104: 771. 5. Institut Municipal d’Investigació Mèdica (IMIM). Manual de puntuació de la versión española del Cuestionario de Salud SF-36. Barcelona. 2000

6. SURESHKUMAR KK, MUBIN T, MIKHAEL N et al. Assessment of quality of life after simultaneous pancreas-kidney transplantation. Am J Kidney Dis 2002: 39: 1300.7. SURESHKUMAR KK, PATEL BM, MARKATOS A et al. Quality of life after organ transplantation in type 1 diabetics with end-stage renal disease. Clin Transplant 2006: 20(1): 19.

8. ESMATJES E, RICART MJ, FERNANDEZ-CRUZ L et al. Quality of life after successful pancreas-kidney transplantation. Clin Transplant 1994: 8(2 Pt 1): 75.

9. ROCCO MV, GASSMAN JJ, WANG SR et al. Cross-sectional study of quality of life and symptoms in chronic renal disease patients: the Modification of Diet in Renal Disease Study. Am J Kidney Dis 1997: 29: 888.

10. YANG SC, KUO PW, WANG JD et al. Quality of Life and Its Determinants of Haemodialysis Patients in Taiwan Measured With WHOQOL-BREF(TW). Am J Kidney Dis 2005: 46: 635. 11. ISLA P. Los Procesos asistenciales en los enfermos trasplantados. El caso del trasplante de riñón y páncreas. Tesis Doctoral. Universidad de Alicante. Abril, 2006

12. MATAS AJ, HALBERT RJ, BARR ML et al. Life satisfaction and adverse effects in renal transplant recipients: a longitudinal analysis. Clin Transplant 2002; 16: 113.

13. JOSEPH JT, BAINES LS, MORRIS MC et al. Quality of life after kidney and pancreas transplantation: a review. Am J Kidney Dis 2003; 42: 431.

14. MÁRTINEZ-CASTELAO A, GÓRRIZ JL, GARCÍA-LÓPEZ F et al. Perceived health-related quality of life and comorbidity in diabetic patients starting dialysis (CALVIDIA study) J Nephrol 2004: 17: 544.

15. GORLÉN T, EKEBERG O, ABDELNOOR M et al. Quality of life after kidney transplantation: a 10-22 years follow-up. Scand J Urol Nephrol 1993: 27: 89.

16. REBOLLO P, BOBES J, GONZALEZ MP et al. Factores asociados a la calidad de vida relacionada con la salud (CVRS) de los pacientes en terapia renal sustitutiva (TRS). Nefrologia 2000: 20: 171.

17. HORINA JH, HOLZER H, REISINGER EC et al, Elderly patients and chronic haemodialysis. Lancet 1992: 339: 183.

18. HADER SL, SMITH DK, MOORE JS et al. HIV infection in women in the United States: status at the Millennium. JAMA 2001: 285: 1186. 
19. DEW MA, SWITZER GE, GOYCOOLEA JM et al. Does transplantation produce quality of life benefits? A quantitative analysis of the literature. Transplantation 1997: 64: 1261.

20. ICHIKAWA Y, FUJISAWA M, HIROSE E et al. Quality of life in kidney transplant patients. Transplantation Proceedings 2000: 32: 1815.21. BUNZEL B, LAEDERACHHOFMANN K, SCHUBERT MT. Patients benefit - partners suffer? The impact of heart transplantation on the partner relationship. Transpl Int 1999: 12: 33.

22. PÉREZ SAN GREGORIO MA, MARTÍN RODRÍGUEZ A., GALÁN RODRÍGUEZ A. Problemas psicológicos asociados al trasplante de órganos. Int J Clin Health Psychol 2005: 5: 99.

23. PONTON P, RUPOLO GP, MARCHINI F et al. Quality-of-life change after kidney transplantation. Transplant Proc 2001: 33: 1887.

24. SESSO R, RODRÍGUEZ-NETO JF, FERAZ MB. Impact of socioeconomic status on the quality of life of ESRD patients. Am J Kidney Dis 2003: 41: 186.

25. PEARCE IA, ILANGO B, SELLS RA et al. Stabilisation of diabetic retinopathy following simultaneous pancreas and kidney transplant. Br J Ophthalmol 2000: 84: 736.

26. NAVARRO $\mathrm{X}$, SUTHERLAND DE, KENNEDY WR. Long-term effects of pancreatic transplantation on diabetic neuropathy. Ann Neurol 1998: 44: 149.

27. ISRANI AK, FELDMAN HI, PROPERT KJ et al. Impact of simultaneous kidneypancreas transplant and timing of transplant on kidney allograft survival. Am J Transplant 2005: 5: 374 .

28. BIESENBACH G, KONIGSRAINER A, GROSS $\mathrm{C}$ et al. Progression of macrovascular diseases is reduced in type 1 diabetic patients after more than 5 years successful combined pancreas-kidney transplantation in comparison to kidney transplantation alone. Transpl Int 2005: 18: 1054.

29. GONZALEZ-POSADA JM, PEREZ TAMAJON L, CABALLERO A et al. Evolución a corto plazo de los factores de riesgo cardiovascular tras el trasplante renopancreático. Nefrología 2005: 25: 315.

30. FRANKE GH, REIMER J, PHILIPP T et al. Aspects of quality of life through endstage renal disease. Qual Life Res 2003: 12: 103.

31. BAINES LS, JOSEPH JT, JINDAL RM. Prospective randomized study of individual and group psychotherapy versus controls in recipients of renal transplants. Kidney Int 2004: 65: 193. 
Table 1. Age, sex, mean years' duration of DM1 and mean length of RRT by study group

\begin{tabular}{|c|c|c|c|c|c|c|c|}
\hline & \multirow{2}{*}{} & \multirow{2}{*}{$\begin{array}{c}\text { Duration of DM1 } \\
\text { (before Tx) }\end{array}$} & $\begin{array}{c}\text { Length of } \\
\text { RRT }\end{array}$ & \multicolumn{2}{|c|}{ Sex } & \multicolumn{2}{c|}{ Age } \\
\cline { 5 - 8 } & & & Male & Female & Men & Women \\
\hline $\begin{array}{c}\text { SPK } \\
\text { transplant } \\
\text { recipients }\end{array}$ & 69 & $23.8 \pm 6.3$ & $20.2 \pm 13.4$ & 41 & 28 & $41.78 \pm 6.5$ & $38.5 \pm 7.0$ \\
\hline $\begin{array}{c}\text { Patients } \\
\text { under RRT }\end{array}$ & 34 & $26.9 \pm 8.4$ & $33.3 \pm 28.8$ & 24 & 10 & $41.6 \pm 8.5$ & $45.9 \pm 5.8$ \\
\hline Significance & & $\mathbf{0 . 0 3}^{\mathrm{a}}$ & $\mathbf{0 . 0 2}^{\mathbf{a}}$ & \multicolumn{2}{|c|}{$0.18^{\mathrm{b}}$} & \multicolumn{2}{|c|}{$0.31^{\mathrm{a}}$} \\
\hline
\end{tabular}

a $\mathrm{t}$-test significance

${ }^{\mathrm{b}}$ Chi-squared test significance 
Table 2. Current perceived health status compared with health 1 year previously by sex

\begin{tabular}{|l|c|c|c|c|}
\hline Current health status & \multicolumn{2}{|c|}{ Men } & \multicolumn{2}{c|}{ Women } \\
\hline & RRT & SPK Tx & RRT & SPK Tx \\
\hline Much better than 1 year ago & $1(4.2 \%)$ & $18(43.9 \%)$ & $0(0 \%)$ & $8(28.6 \%)$ \\
\hline Somewhat better than 1 year ago & $8(33.3 \%)$ & $3(7.3 \%)$ & $3(30 \%)$ & $5(17.9 \%)$ \\
\hline More or less the same as 1 year ago & $7(29.2 \%)$ & $18(43.9 \%)$ & $3(30 \%)$ & $13(46.4 \%)$ \\
\hline Somewhat worse than 1 year ago & $5(20.8 \%)$ & $2(4.9 \%)$ & $4(40 \%)$ & $2(7.1 \%)$ \\
\hline Much worse than 1 year ago & $3(12.5 \%)$ & $0(0 \%)$ & $0(0 \%)$ & $0(0 \%)$ \\
\hline & \multicolumn{2}{|c|}{23.737} & \multicolumn{2}{|c|}{8.147} \\
\hline Fisher's exact test & \multicolumn{2}{|c|}{$\mathbf{0 . 0 0 1}$} & \multicolumn{2}{|c|}{025} \\
\hline Exact significance (bilateral) & \multicolumn{3}{|c|}{}
\end{tabular}


Table 3. Means, standard deviation and statistical significance of the eight SF-36 dimensions in SPK transplant recipients and patients with DM1 under RRT (scale: $0=100$ )

\begin{tabular}{|c|c|c|c|c|c|c|c|c|c|}
\hline $\begin{array}{l}\text { RRT } \\
\text { or } \\
\text { SPK } \\
\text { Tx }\end{array}$ & & $\begin{array}{l}\text { Physical } \\
\text { functioning }\end{array}$ & $\begin{array}{l}\text { Role- } \\
\text { physical }\end{array}$ & Bodily pain & $\begin{array}{l}\text { General } \\
\text { health }\end{array}$ & Vitality & $\begin{array}{c}\text { Social } \\
\text { functioning }\end{array}$ & $\begin{array}{c}\text { Role- } \\
\text { Emotional }\end{array}$ & $\begin{array}{l}\text { Mental } \\
\text { health }\end{array}$ \\
\hline \multirow[t]{2}{*}{$\begin{array}{l}\mathrm{RRT} \\
(\mathrm{N}=34) \\
\end{array}$} & Mean & 57.4506 & 55.1471 & 59.8235 & 35.7941 & 46.1176 & 65.4412 & 58.8118 & 61.1765 \\
\hline & SD & 31.23815 & 45.13423 & 28.53331 & 18.97172 & 22.66457 & 31.84046 & 44.23690 & 23.68540 \\
\hline $\begin{array}{l}\text { SPK } \\
\text { Tx } \\
(\mathrm{N}=69)\end{array}$ & Mean & 82.8986 & 79.7101 & 77.9130 & 56.1594 & 69.1304 & 82.4275 & 77.7725 & 72.4638 \\
\hline & SD & $19.23932^{a}$ & $33.56166^{b}$ & $23.65421^{a}$ & $19.66904^{\mathrm{a}}$ & $22.67021^{a}$ & $23.70922^{b}$ & $38.63493^{b}$ & $21.74219^{a}$ \\
\hline \multicolumn{2}{|c|}{ Significance } & 0.001 & 0.008 & 0.001 & 0.001 & 0.001 & 0.013 & 0.017 & 0.018 \\
\hline
\end{tabular}

a t-test significance

${ }^{\text {b }}$ U Mann-Whitney test significance 
Table 4. Means, standard deviation and statistical significance of the eight SF-36 dimensions in SPK transplant recipients by sex

\begin{tabular}{|r|r|r|r|r|r|r|r|r|}
\hline Sex & $\begin{array}{c}\text { Physical } \\
\text { functioning }\end{array}$ & $\begin{array}{c}\text { Role- } \\
\text { physical }\end{array}$ & $\begin{array}{c}\text { Bodily } \\
\text { pain }\end{array}$ & $\begin{array}{c}\text { General } \\
\text { health }\end{array}$ & Vitality & $\begin{array}{c}\text { Social } \\
\text { functioning }\end{array}$ & $\begin{array}{c}\text { Role- } \\
\text { emotional }\end{array}$ & $\begin{array}{c}\text { Mental } \\
\text { health }\end{array}$ \\
\hline $\begin{array}{r}\text { Men } \\
\text { Ne=21 }\end{array}$ & 84.1463 & 84.1463 & 82.2927 & 57.7317 & 73.7805 & 87.8049 & 83.7341 & 79.4146 \\
$\mathrm{SD}$ & 18.93748 & 29.97713 & 20.62795 & 19.30547 & 21.58647 & 18.64299 & 34.25926 & 17.51710 \\
\hline $\begin{array}{r}\text { Women } \\
\text { Mean } \\
\mathrm{N}=28\end{array}$ & 81.0714 & 73.2143 & 71.50000 & 53.8571 & 62.3214 & 74.5536 & 69.0429 & 62.2857 \\
$\mathrm{SD} \quad 19.87727$ & 37.84017 & 26.58947 & 20.32097 & 22.87171 & 28.15346 & 43.44512 & 23.56214 \\
\hline
\end{tabular}


Table 5. Means, standard deviation and statistical significance of the eight SF-36 dimensions in patients with DM1 under RRT by sex

\begin{tabular}{|c|c|c|c|c|c|c|c|c|}
\hline Sex & $\begin{array}{c}\text { Physical } \\
\text { functioning }\end{array}$ & $\begin{array}{c}\text { Role- } \\
\text { physical }\end{array}$ & $\begin{array}{l}\text { Bodily } \\
\text { pain }\end{array}$ & $\begin{array}{c}\text { General } \\
\text { health }\end{array}$ & Vitality & $\begin{array}{c}\text { Social } \\
\text { functioning }\end{array}$ & $\begin{array}{c}\text { Role- } \\
\text { emotional }\end{array}$ & $\begin{array}{l}\text { Mental } \\
\text { health }\end{array}$ \\
\hline $\begin{array}{l}\text { Men } \\
\text { Mean } \\
N=24\end{array}$ & 62.3608 & 68.7500 & 67.5000 & 37.5417 & 49.5000 & 73.9583 & 74.9875 & 65.6667 \\
\hline SD & 30.30841 & 43.76941 & 26.53769 & 18.59401 & 22.75473 & 30.15284 & 38.38938 & 23.38090 \\
\hline $\begin{array}{l}\text { Women } \\
\text { Mean }\end{array}$ & 45.6660 & 22.5000 & 41.4000 & 31.6000 & 38.0000 & 45.0000 & 19.9900 & 50.4000 \\
\hline SD & 31.81006 & 29.93047 & 25.43925 & 20.21111 & 22.75473 & 27.13137 & 32.19846 & 21.84389 \\
\hline Significance & $0.137^{\mathrm{a}}$ & $0.008^{b}$ & $0.010^{\mathrm{a}}$ & $0.423^{a}$ & $0.148^{a}$ & $0.013^{b}$ & $0.002^{b}$ & $0.118^{\mathrm{a}}$ \\
\hline
\end{tabular}


Table 6. Multivariate Analysis. Dimensions of mental health, physical functioning, bodily pain, general health, vitality, role-physical, role-emotional and social functioning.

\begin{tabular}{|c|c|c|c|}
\hline Dependent variable & Independent variables & Model Coefficients & Significance \\
\hline Mental health $^{a}$ & $\begin{array}{l}\text { 1. (Constant) } \\
\text { Age } \\
\text { Tx SPK or RRT } \\
\text { Sex } \\
\text { DM1 duration (years) }\end{array}$ & $\begin{array}{r}64,436 \\
, 702 \\
11,596 \\
-14,608 \\
-, 966\end{array}$ & $\begin{array}{r}<0.001 \\
0.036 \\
0.010 \\
0.001 \\
0.005\end{array}$ \\
\hline $\begin{array}{l}\text { physical functioning }^{a} \\
\text { (Transformed) }\end{array}$ & $\begin{array}{l}\text { 1. (Constant) } \\
\text { Age } \\
\text { Tx SPK or RRT } \\
\text { Sex }\end{array}$ & $\begin{array}{r}543,42 \\
-133,07 \\
3258,98 \\
-141,71\end{array}$ & $\begin{array}{r}0.001 \\
\mathbf{0 . 0 0 3} \\
<0.001 \\
0.083\end{array}$ \\
\hline Bodily pain $^{a}$ & $\begin{array}{l}\text { 1. Constant) } \\
\text { Tx SPK or RRT } \\
\text { Sex } \\
\text { DM1 duration (years) }\end{array}$ & $\begin{array}{r}88,351 \\
16,547 \\
-14,032 \\
-, 998 \\
\end{array}$ & $\begin{array}{r}<0.001 \\
0.001 \\
0.005 \\
0.003 \\
\end{array}$ \\
\hline General health $^{a}$ & $\begin{array}{l}\text { 1. (Constant) } \\
\text { Age } \\
\text { Tx SPK or RRT }\end{array}$ & $\begin{array}{r}38,733 \\
-, 515 \\
19,128\end{array}$ & $\begin{array}{r}0.006 \\
0.053 \\
<0.001 \\
\end{array}$ \\
\hline Vitalidty $^{b}$ & $\begin{array}{l}\text { Intersection } \\
\text { Sex } \\
\text { Tx SPK or RRT }\end{array}$ & $\begin{array}{r}62,314 \\
11,471 \\
-24,294 \\
\end{array}$ & $\begin{array}{r}<0.001 \\
0.013 \\
<0.001 \\
\end{array}$ \\
\hline Role-fhysical $^{c}$ & $\begin{array}{l}\text { DM1 duration (years) } \\
\text { Age } \\
\text { Sex } \\
\text { Tx SPK or RRT }\end{array}$ & \begin{tabular}{r|}
$2,031 \mathrm{E}-02$ \\
$-5,501 \mathrm{E}-02$ \\
1,263 \\
$-1,387$
\end{tabular} & $\begin{array}{l}0.062 \\
0.059 \\
\mathbf{0 . 0 0 3} \\
\mathbf{0 . 0 0 2}\end{array}$ \\
\hline Role- Emotional $^{\mathrm{c}}$ & \begin{tabular}{|l} 
Sex \\
Tx SPK or RRT
\end{tabular} & $\begin{array}{r}1,286 \\
-1,197\end{array}$ & $\begin{array}{l}0.003 \\
0.007\end{array}$ \\
\hline Social functioning $^{c}$ & \begin{tabular}{|l} 
Sex \\
Tx SPK or RRT
\end{tabular} & $\begin{array}{r}1,225 \\
-1,189 \\
\end{array}$ & $\begin{array}{l}0.002 \\
0.003\end{array}$ \\
\hline
\end{tabular}


Table 7. Mean range of SF-36 dimensions in patients SPK transplant recipients by study year

\begin{tabular}{|c|c|c|c|c|c|c|c|c|c|}
\hline YEAR & $\mathrm{n}$ & $\begin{array}{l}\text { Physical } \\
\text { functioning }\end{array}$ & $\begin{array}{c}\text { Role- } \\
\text { physical }\end{array}$ & $\begin{array}{l}\text { Bodily } \\
\text { pain }\end{array}$ & $\begin{array}{c}\text { General } \\
\text { health }\end{array}$ & Vitality & $\begin{array}{c}\text { Social } \\
\text { functioning }\end{array}$ & $\begin{array}{c}\text { Role- } \\
\text { emotional }\end{array}$ & $\begin{array}{l}\text { Mental } \\
\text { health }\end{array}$ \\
\hline & & \multicolumn{8}{|c|}{ Mean range } \\
\hline 1998 & 10 & 31.05 & 32.80 & 34.40 & 35.40 & 28.15 & 27.45 & 33.75 & 30.00 \\
\hline 1999 & 13 & 39.08 & 41.62 & 35.04 & 39.15 & 44.50 & 37.58 & 37.15 & 42.69 \\
\hline 2000 & 17 & 21.62 & 27.35 & 32.06 & 25.53 & 25.68 & 32.03 & 33.65 & 31.97 \\
\hline 2001 & 17 & 37.79 & 32.00 & 33.97 & 33.91 & 35.76 & 33.68 & 31.00 & 30.85 \\
\hline \multirow[t]{2}{*}{2002} & 12 & 48.88 & 44.75 & 41.08 & 45.13 & 42.54 & 44.58 & 41.29 & 41.00 \\
\hline & & \multicolumn{8}{|c|}{ Kruskal Wallis test } \\
\hline Chi-squared & & 15.203 & 10.038 & 1.663 & 7.492 & 9.545 & 5.582 & 3.450 & 4.753 \\
\hline Df & & 4 & 4 & 4 & 4 & 4 & 4 & 4 & 4 \\
\hline $\begin{array}{c}\text { Asintotic } \\
\text { significance. }\end{array}$ & & .004 & .040 & .797 & .112 & .049 & .233 & .486 & .314 \\
\hline
\end{tabular}


Table 8. Comparison of the values obtained in each of the SF-36 dimensions with mean values in the Spanish reference population by sex and SPK TX or RRT

\begin{tabular}{|c|c|c|c|c|c|c|c|c|c|c|}
\hline GROUP & Sex & $\mathrm{n}$ & $\begin{array}{c}\text { Physical } \\
\text { functioning }\end{array}$ & $\begin{array}{c}\begin{array}{c}\text { Role- } \\
\text { physical }\end{array} \\
\end{array}$ & $\begin{array}{l}\text { Bodily } \\
\text { pain }\end{array}$ & $\begin{array}{c}\text { General } \\
\text { health }\end{array}$ & Vitality & $\begin{array}{c}\text { Social } \\
\text { functioning }\end{array}$ & $\begin{array}{c}\text { Role- } \\
\text { emotional }\end{array}$ & $\begin{array}{l}\text { Mental } \\
\text { health }\end{array}$ \\
\hline & & & \multicolumn{8}{|c|}{ Exact significance binomial test (observed proportion $\leq$ reference population value) } \\
\hline \multirow[t]{2}{*}{ SPK Tx } & M & 41 & $\begin{array}{c}0.75 \\
(0.46)\end{array}$ & $\begin{array}{l}\mathbf{0 . 0 1 2} \\
(0.29) \\
\end{array}$ & $\begin{array}{c}0.34 \\
(0.41) \\
\end{array}$ & $\begin{array}{l}\mathbf{0 . 0 0 1} \\
(0.83) \\
\end{array}$ & $\begin{array}{l}\mathbf{0 . 0 2 8} \\
(0.32)\end{array}$ & $\begin{array}{c}0.34 \\
(0.41) \\
\end{array}$ & $\begin{array}{l}\mathbf{0 . 0 0 1} \\
(0.22)\end{array}$ & $\begin{array}{c}0.34 \\
(0.41) \\
\end{array}$ \\
\hline & $\mathrm{F}$ & 28 & $\begin{array}{c}0.18 \\
(0.64)\end{array}$ & $\begin{array}{c}0.57 \\
(0.43)\end{array}$ & $\begin{array}{c}0.34 \\
(0.61)\end{array}$ & $\begin{array}{l}\mathbf{0 . 0 0 1} \\
(0.86)\end{array}$ & $\begin{array}{c}0.85 \\
(0.46)\end{array}$ & $\begin{array}{c}0.34 \\
(0.61)\end{array}$ & $\begin{array}{c}0.18 \\
(0.36)\end{array}$ & $\begin{array}{c}0.18 \\
(0.64)\end{array}$ \\
\hline \multirow[t]{2}{*}{ RRT } & M & 24 & $\begin{array}{c}\mathbf{0 . 0 2} \\
(0.83)\end{array}$ & $\begin{array}{c}0.3 \\
(0.38)\end{array}$ & $\begin{array}{c}\mathbf{0 . 0 5} \\
(0.71)\end{array}$ & $\begin{array}{l}\mathbf{0 . 0 0 1} \\
(0.96)\end{array}$ & $\begin{array}{c}\mathbf{0 . 0 5} \\
(0.71)\end{array}$ & $\begin{array}{c}0.83 \\
(0.54)\end{array}$ & $\begin{array}{c}0.3 \\
(0.38)\end{array}$ & $\begin{array}{c}0.3 \\
(0.63)\end{array}$ \\
\hline & $F$ & 10 & $\begin{array}{l}\mathbf{0 . 0 0 2} \\
(0.17)\end{array}$ & $\begin{array}{l}\mathbf{0 . 0 0 2} \\
(0.63)\end{array}$ & $\begin{array}{l}\mathbf{0 . 0 2 1} \\
(0.90)\end{array}$ & $\begin{array}{c}\mathbf{0 . 0 0 2} \\
(1.0)\end{array}$ & $\begin{array}{l}\mathbf{0 . 0 2 1} \\
(0.90)\end{array}$ & $\begin{array}{l}\mathbf{0 . 0 2 1} \\
(0.90)\end{array}$ & $\begin{array}{l}\mathbf{0 . 0 2 1} \\
(0.90)\end{array}$ & $\begin{array}{l}\mathbf{0 . 0 2 1} \\
(0.10)\end{array}$ \\
\hline
\end{tabular}

Table 9. Comparison of the values obtained in each of the SF-36 dimensions by SPK transplant recipients with mean values in the Spanish reference population by year of SPK TX

\begin{tabular}{|c|c|c|c|c|c|c|c|c|c|}
\hline YEAR & $\mathrm{n}$ & $\begin{array}{l}\text { Physical } \\
\text { functioning }\end{array}$ & $\begin{array}{c}\text { Role- } \\
\text { physical }\end{array}$ & $\begin{array}{l}\text { Bodily } \\
\text { pain }\end{array}$ & $\begin{array}{c}\text { General } \\
\text { health }\end{array}$ & Vitality & $\begin{array}{c}\text { Social } \\
\text { functioning }\end{array}$ & $\begin{array}{c}\text { Role- } \\
\text { emotional }\end{array}$ & $\begin{array}{l}\text { Mental } \\
\text { health }\end{array}$ \\
\hline & & \multicolumn{8}{|c|}{ Exact significance binomial test (Observed proportion $\leq$ reference population value) } \\
\hline 1998 & 10 & $\begin{array}{c}0.34 \\
(0.70) \\
\end{array}$ & $\begin{array}{c}0.75 \\
(0.40) \\
\end{array}$ & $\begin{array}{c}1.00 \\
(0.50)\end{array}$ & $\begin{array}{c}0.34 \\
(0.70) \\
\end{array}$ & $\begin{array}{c}0.75 \\
(0.60) \\
\end{array}$ & $\begin{array}{c}0.75 \\
(0.60) \\
\end{array}$ & $\begin{array}{c}0.34 \\
(0.30) \\
\end{array}$ & $\begin{array}{c}0.75 \\
(0.60) \\
\end{array}$ \\
\hline 1999 & 13 & $\begin{array}{l}1.00 \\
(0.54)\end{array}$ & $\begin{array}{c}\mathbf{0 . 0 0 2} \\
(0.15)\end{array}$ & $\begin{array}{c}1.00 \\
(0.50)\end{array}$ & $\begin{array}{l}\mathbf{0 . 0 2 2} \\
(0.85)\end{array}$ & $\begin{array}{l}0.092 \\
(0.23)\end{array}$ & $\begin{array}{c}0.58 \\
(0.38)\end{array}$ & $\begin{array}{l}0.092 \\
(0.23)\end{array}$ & $\begin{array}{c}1.00 \\
(0.46)\end{array}$ \\
\hline 2000 & 17 & $\begin{array}{l}\mathbf{0 . 0 0 2} \\
(0.88) \\
\end{array}$ & $\begin{array}{c}0.62 \\
(0.59) \\
\end{array}$ & $\begin{array}{c}1.00 \\
(0.53) \\
\end{array}$ & $\begin{array}{l}\mathbf{0 . 0 0 1} \\
(1.00) \\
\end{array}$ & $\begin{array}{c}0.62 \\
(0.59) \\
\end{array}$ & $\begin{array}{c}0.33 \\
(0.65) \\
\end{array}$ & $\begin{array}{c}0.14 \\
(0.29) \\
\end{array}$ & $\begin{array}{c}1.00 \\
(0.46) \\
\end{array}$ \\
\hline 2001 & 17 & $\begin{array}{c}0.33 \\
(0.35) \\
\end{array}$ & $\begin{array}{c}0.62 \\
(0.59) \\
\end{array}$ & $\begin{array}{c}1.00 \\
(0.53)\end{array}$ & $\begin{array}{l}\mathbf{0 . 0 0 2} \\
(0.88) \\
\end{array}$ & $\begin{array}{c}0.14 \\
((0.29) \\
\end{array}$ & $\begin{array}{c}1.00 \\
(0.53)\end{array}$ & $\begin{array}{c}1.00 \\
(0.53) \\
\end{array}$ & $\begin{array}{c}1.00 \\
(0.53) \\
\end{array}$ \\
\hline 2002 & 12 & $\begin{array}{l}\mathbf{0 . 0 3 9} \\
(0.17)\end{array}$ & $\begin{array}{l}\mathbf{0 . 0 0 6} \\
(0.08)\end{array}$ & $\begin{array}{c}0.38 \\
(0.33)\end{array}$ & $\begin{array}{c}0.38 \\
(0.67)\end{array}$ & $\begin{array}{l}\mathbf{0 . 0 3 9} \\
(0.17)\end{array}$ & $\begin{array}{c}0.14 \\
(0.25)\end{array}$ & $\begin{array}{l}\mathbf{0 . 0 0 6} \\
(0.08)\end{array}$ & $\begin{array}{c}0.77 \\
(0.42)\end{array}$ \\
\hline
\end{tabular}

